\title{
Eficacia de inhibidores de nitrito de calcio (CNI) en concreto agrietado
}

\section{Effectiveness of calcium nitrate inhibitor (CNI) in cracked concrete}

\author{
Pedro Montes-Garcia*1, H. Z. López-Calv**, T. W. Bremner** \\ * CIIDIR Oaxaca, IPN, Oxaca, MÉXICO \\ ** University of New Brunswick, CANADÁ
}

Contribución. Mejor artículo Contribution. Best paper award Conpat 2009

PAG. $233-244$

Resumen

\begin{abstract}
En el presente estudio se investigó la eficacia de un inhibidor a base de nitrito de calcio como método para prevenir la corrosión de acero de refuerzo en losas de concreto agrietado. Para tal efecto se desarrolló un diseño factorial para evaluar el efecto del agrietamiento en concreto considerando ancho de grieta y relación agua/cemento como factores. Luego, se evaluó el efecto de una dosis constante de $25 \mathrm{l} / \mathrm{m}^{3}$ de inhibidor de nitrito de calcio(CNI) en concreto con una relación A/C de 0.4 que contenía diferentes anchos de grieta. La variable respuesta fue la densidad de corrosión obtenida mediante lecturas de resistencia de polarización lineal en losas pequeñas de concreto armado que tenían recubrimiento de 20 mm. Las losas fueron expuestas a un ambiente marino natural durante cinco años con dos ciclos de humedecimiento y secado por día en la bahía de Fundy, Maine, EE.UU. Las muestras también fueron inspeccionadas visualmente de manera regular y el daño en la superficie registrado. Se constató que para la mayoría de los casos, el uso de inhibidor a base de $\mathrm{CNI}$ fue benéfico tanto en concreto agrietado como en no agrietado.
\end{abstract}

Palabras Clave: Cementos alcalinos, resistencias mecánicas, durabilidad, aplicaciones

\begin{abstract}
The effectiveness of calcium nitrite based corrosion inhibitor as a prevention method of steel reinforcing bars embedded in cracked concrete slabs was investigated. A factorial design was developed to evaluate the effect of cracking in concrete considering crack width and water-to-cement ratio as factors. Then, the effect of a constant dosage of $25 \mathrm{~L} / \mathrm{m}^{3}$ of Calcium Nitrate Inhibitor (CNI) on different crack sizes for 0.4 w/c ratio concrete was evaluated. The response was the corrosion current density using linear polarization resistance of small-scale concrete slabs containing steel reinforcement with a cover depth of $20 \mathrm{~mm}$. The slabs were exposed to a natural marine environment during five years with two cycles of wetting and drying per day at the Fundy Bay, Maine, U.S. A. The specimens were also visually inspected on regular basis and the surface damage was recorded. It was found that for most of the cases the use of CNI inhibitor was beneficial in both uncracked and cracked concrete.
\end{abstract}

Keywords: Calcium nitrite, concrete cracking, corrosion, corrosion current density

\section{Introducción}

El deterioro de infraestructura causada por la corrosión de acero de refuerzo es un problema que ha ido aumentando con los años. A pesar de los esfuerzos por invertir en fuentes importantes de investigación, las cuales han llevado a escribir cientos de artículos sobre el tema, las pérdidas económicas aun son substanciales (Broomfield 1997 y Koch et al., 2001). Algunas razones de este problema son la carencia de conocimiento acerca de las características intrínsecas del concreto, cargas de servicio reales que actúan en las estructuras, mecanismos de deterioro involucrados y la agresividad de entorno ambiental.

\section{Introduction}

The deterioration of infrastructure caused by the corrosion of steel reinforcement is a problem that has been increasing over the years. In spite of efforts by investing significant resources in research, which has led to writing thousands of articles on the topic, the economic losses are still substantial (Broomfield 1997 and Koch et al., 2001). Some causes of this problem are the lack of knowledge of the intrinsic properties of concrete, real service loads acting on the structures, deterioration mechanisms involved and aggressiveness of the surrounding environment.

\footnotetext{
1 Autor de correspondencia / Corresponding author

E-mail: pmontes@ipn.mx
} 
La relación agua-cemento $(\mathrm{A} / \mathrm{C})$ es uno de los parámetros más importantes que afectan las propiedades a largo plazo del concreto. El valor de la relación A/C es importante para muchos aspectos de la durabilidad, sin embargo también se ha sugerido que determina la durabilidad o la permeabilidad del concreto (Neville 1999). De acuerdo a esto, la relación A/C no es un indicador de durabilidad; es en su interacción con otros factores donde necesita ser investigada.

Se sugiere que el inhibidor de nitrito de calcio (CNI) mejora significativamente la resistencia a la corrosión del acero en el concreto con valores $\mathrm{A} / \mathrm{C}$ bajo 0.5 (Berke et al., 1988). Sin embargo, algunas investigaciones indicaron el efecto detrimetral del nitrato de calcio en las propiedades del concreto y su desempeño aparentemente pobre para prevenir la corrosión de las barras de refuerzo de acero. Nmai y McDonald (1999) informaron que el $\mathrm{CNI}$ parece no ser efectivo para prevenir la corrosión, a menos que se agregue una amplia cantidad en la mezcla.

En consideración al tamaño de la grieta, se informó que su ancho en menos de $0.5 \mathrm{~mm}$ afecta el desarrollo de corrosión, pero que éste no tiene una influencia significativa en procesos de corrosión posteriores. (Francois y Arliguie, 1999). Una investigación adicional sugiere que la corrosión sólo se ve ligeramente afectada por la presencia de grietas y se debe asegurar protección de corrosión usando una cobertura de concreto de calidad y profundidad adecuada (Schießel y Raupach, 1997), además el desarrollo de la corrosión no está influenciado por el ancho de la grieta o por la grieta propiamente tal (Francois y Arliguie, 1998). Jacobsen et al. (1998) concluyeron que una grieta menor de $0.4 \mathrm{~mm}$ no afecta en forma adversa a la corrosión del acero en comparación con el acero en concreto no agrietado, y algunos otros factores como el medio ambiente, calidad y nuevamente el grosor de la cubierta son más importantes. Sin embargo se observó que el CNI es más efectivo en relaciones concreto $\mathrm{A} / \mathrm{C}$ altas y bajas en grietas de concreto reforzadas cuando se sometían a períodos extensos o breves de exposición de estimulación marina (Schießel y Dauberschmidt, 2000). En estudios recientes del concreto agrietado, se encontró que el CNI era relativamente inefectivo para prevenir la corrosión de losas pequeñas sometidas a un ambiente natural marino (Kondratova et al., 2003). Consecuentemente es necesario más trabajo en esta área para proporcionar información adicional acerca de la influencia de CNI, ancho de grieta y la posible interacción entre ellas en el desarrollo de la corrosión de barras de concreto reforzado.
The water-to-cement ratio is one of the most important parameters affecting the long-term properties of concrete. The value of the $w / c$ ratio is relevant to many aspects of durability; however, it has also been suggested that the $w / c$ ratio alone does not determine the durability or even the permeability of the concrete (Neville 1999). According to this, the w/c ratio is not an indicator of durability; it is its interaction with some other factors that need to be investigated.

It is suggested that calcium nitrite inhibitor (CNI) significantly improves the corrosion resistance of steel in concrete with w/c values under 0.5 (Berke et al., 1988). However, some research indicated detrimental effects of calcium nitrite on the properties of concrete and that it has apparently poor performance in preventing corrosion of steel reinforcing bars. Nmai and MacDonald reported that $\mathrm{CNI}$ seems to be ineffective at reducing corrosion, unless a large amount is added to the mixture (Nmai and McDonald 1999).

Regarding the effect of size of the crack, it was reported that crack width of less than $0.5 \mathrm{~mm}$ affects the development of corrosion, but its width has not a significant influence at later stages in the corrosion process (Francois and Arliguie 1999). Additional research suggests that corrosion is only slightly affected by the presence of cracks and corrosion protection must be assured by the use of adequate quality concrete and suitable cover depth (Schießel and Raupach 1997), and the development of corrosion is not influenced by the crack width or by the crack itself (Francois and Arliguie 1998). Jacobsen et al. (1998) concluded that crack widths smaller that $0.4 \mathrm{~mm}$ do not adversely affect corrosion of steel as compared to steel in uncracked concrete, and some other factors such as environment, quality and again thickness of the cover are more important. However, CNI has been reported to be effective in high and low $w / c$ ratio concrete in cracked reinforced concrete when subjected to short and extended periods of simulated marine exposure (Schießel and Dauberschmidt 2000). In recent studies in cracked concrete, CNI was found to be relatively ineffective in preventing corrosion of small slabs subjected to a natural marine environment (Kondratova et al., 2003). Consequently, more work in this area is necessary to provide additional information about the influence of $\mathrm{CNI}$, crack width and the possible interaction between them in the development of corrosion of reinforcing bars in concrete. 
Se usaron inhibidores de nitrato de calcio para prevenir la corrosión, sin embargo, la mayoría de los estudios se hicieron en ambientes estimulados y sin considerar el agrietamiento del concreto. En vista de esto, se investigaron dos factores que afectan a la corrosión, principalmente la relación agua cemento y el grado de agrietamiento del concreto. Entonces, se evaluó el efecto de una dosificación constante de $25 \mathrm{l} / \mathrm{m}^{3}$ de CNI sobre distintos tamaños de agrietamiento para una $\mathrm{A} / \mathrm{C}$ de 0.4 . La respuesta fue la medida de densidad actual usando la técnica de Lectura de Polarización lineal en una losa pequeña de concreto que contenía acero reforzado, la cual fue sometida a un ambiente marino natural durante 5 años.

\section{Trabajo experimental}

\subsection{Programa y proceso experimental}

Se consideraron en este programa experimental contienen muestras diferentes de cuatro $\mathrm{A} / \mathrm{C}$ diferentes y cinco condiciones de agrietamiento, para un estudio de corrosión a largo plazo en un ambiente marino natural. Aún más se consideró el efecto $\mathrm{CNI}$ en relación $\mathrm{A} / \mathrm{C} 0.4$ para diferentes condiciones de agrietamiento. La razón de usar sólo esta relación para evaluar la influencia de $\mathrm{CNI}$ se basa en el hecho que aparentemente esta es la máxima relación $\mathrm{A} / \mathrm{C}$ que entrega aspectos de durabilidad (Kosmatka et al., 2002). Para cada combinación fueron ancladas dos losas de concreto que contienen barras de reforzamiento.

En la Tabla 1 se presentan detalles del diseño del experimento.
Calcium nitrite inhibitors have been used to prevent corrosion, however, most of the research has been done in simulated environments and without considering cracking of concrete. In view of this, two factors affecting corrosion were investigated; namely, water-to-cement ratio and the degree of cracking of the concrete. Then, the effect of a constant dosage of 25 $\mathrm{L} / \mathrm{m}^{3}$ of $\mathrm{CNI}$ on different crack sizes for $0.4 \mathrm{w} / \mathrm{c}$ ratio concrete was evaluated. The response was the corrosion current density measured using the Linear Polarization Resistance technique of small scale concrete slabs containing steel reinforcement, which were subjected to a natural marine environment over a period of five years.

\section{Experimental work}

\subsection{Experimental program and procedure}

Specimens containing four different water-tocement ratios and five crack conditions were considered in this experimental program for the long-term study of corrosion in a natural marine environment. Furthermore, the effect of $\mathrm{CNI}$ in $0.4 \mathrm{w} / \mathrm{c}$ ratio for different crack conditions was considered. The reasoning of using only a $0.4 \mathrm{w} / \mathrm{c}$ ratio for evaluating the influence of $\mathrm{CNI}$ is based on the fact that apparently this is the maximum $w / c$ ratio which fulfills durability aspects (Kosmatka et al., 2002). Two concrete slabs containing two reinforcing bars each were cast for every combination.

Details of the design of the experiment are presented in Table 1.

Table 1. Programa piloto muestras de concreto

Table 1. Program layout of concrete specimens

\begin{tabular}{|c|c|c|c|c|c|c||}
\hline \multirow{2}{*}{$\begin{array}{c}\text { A/C } \\
\text { W/C }\end{array}$} & \multirow{2}{*}{$\begin{array}{c}\text { Inhibidor Corrosion / } \\
\text { Corrosion Inhibitor }\end{array}$} & \multicolumn{5}{|c||}{ Ancho de la grieta $(\mathrm{mm}) /$ InCrack Width $(\mathrm{mm})$} \\
\hline 0.30 & -- & 0.1 & 0.2 & 0.3 & 0.4 \\
\hline 0.40 & --- & $\times$ & $\times$ & $\times$ & $\times$ & $\times$ \\
\hline 0.50 & --- & & $\times$ & $\times$ & $\times$ & $\times$ \\
\hline 0.60 & --- & & $\times$ & $\times$ & $\times$ & $\times$ \\
\hline 0.40 & $\mathrm{CNI}$ & $\times$ & $\times$ & $\times$ & $\times$ & $\times$ \\
\hline
\end{tabular}




\section{a) Inspección Visual}

La superficie de la losa de concreto se inspeccionó anualmente y se registró la existencia de losas, grietas adicionales o deterioro del concreto.

\section{b) Monitoreo de la corrosión}

Después de la inspección visual, se usó la técnica de Resistencia de Polarización Lineal (Gamry Inc) para medir la densidad de corriente de la corrosión. Se evaluó el efecto de grietas en diferentes relaciones $\mathrm{A} / \mathrm{C}$ y el de $\mathrm{CNI}$ en concreto agrietado con relación $\mathrm{A} / \mathrm{C}$ 0.4 .

\subsection{Materiales y Preparación de la Muestra}

Se usó un concreto con un tamaño máximo de agregado en $12.5 \mathrm{~mm}, \mathrm{~A} / \mathrm{C} 0.4 \mathrm{~mm}$ y un contenido de aire de $6 \%$. Para mezclas de concreto se usó cemento Portland Tipo CSA 10. La Tabla 2 resume las propiedades físicas y químicas de la composición de cemento usado. En la Tabla 3 se listan las medidas de la mezcla de concreto. Se usaron dos tipos de inhibidores de corrosión en las mezclas.

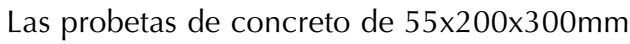
fueron inicialmente pre-agrietadas de acuerdo al proceso descrito previamente (Kondratova, 1999 y Erdogdu et al., 2001). Se eligió un recubrimiento de concreto sobre $20 \mathrm{~mm}$ para escalas de pequeñas losas de concreto. Para pruebas de polarización lineal se dispuso en el centro de cada muestra un contador de electrodo de acero inoxidable de $150 \mathrm{~mm}$. Se adhirieron cables al contador de electrodos y a la barra de reforzamiento (Figura 1). La conexión cable-barra fue cubierta con un compuesto epóxico Resicoat 506610 para prevenir corrosión galvánica.

\section{a) Visual Examination}

The surface of the concrete slabs was annually inspected and the existence of stains, additional cracks or concrete deterioration was recorded.

\section{b) Corrosion Monitoring}

After visual inspection, corrosion current density readings were taken using linear polarization resistance technique (Gamry Inc.). The effect of cracks in different $w / c$ ratios and the effect of $C N I$ in cracked concrete with $0.4 \mathrm{w} / \mathrm{C}$ ratio were evaluated.

\subsection{Materials and Specimen Preparation}

Concrete with a maximum aggregate size of $12.5 \mathrm{~mm}$, water-to-cement ratio of 0.4 , and an air void content of $6 \%$ was used. CSA Type 10 Portland cement was used for concrete mixtures. Table 2 summarizes the physical properties and chemical composition of the cement used. The concrete mixture proportions are listed in Table 3. Two types of corrosion inhibitors were used in the mixtures.

Concrete slabs measured 55x200x300mm and were initially precracked according to the procedure described elsewhere (Erdogdu 1992, Kondratova 1999 and Erdogdu et al., 2001). A concrete cover of $20 \mathrm{~mm}$ was chosen for small scale concrete slabs. For linear polarization testing a 150-mm stainless steel counter electrode was placed in the center of each specimen. Wires were attached to the counter electrode and to the reinforcing bars (Figure 1). The wire-bar connection was patched with an epoxy compound Resicoat 506610 to prevent galvanic corrosion. 
Table 2. Analisis químico y físico del cemento usado en este estudio

Table 2. Chemical and physical analysis of cement used in the study

\begin{tabular}{|c|c|}
\hline Composición Química / Chemical Composition & Resultado de la Prueba/Test Result \\
\hline Oxido de Sílice / Silica $\left(\mathrm{SiO}_{2}\right)$ & $20.6 \%$ \\
\hline Oxido de Aluminio / Alumina $\left(\mathrm{Al}_{2} \mathrm{O}_{3}\right)$ & $5.3 \%$ \\
\hline Oxido de Hierro / Iron Oxide $\left(\mathrm{Fe}_{2} \mathrm{O}_{2}\right)$ & $2.2 \%$ \\
\hline Oxido de Calcio, Total / Calcium Oxide, Total (TCaO) & $63.1 \%$ \\
\hline Oxido de Magnesio / Magnesium Oxide (MgO) & $1.4 \%$ \\
\hline Trióxido de sulfuro / Sulfur Trioxide & $4.1 \%$ \\
\hline Pérdida por Ignición / Loss on Ignition & $2.5 \%$ \\
\hline Cal libre / Free Lime ( $\mathrm{FCaO})$ & $0.6 \%$ \\
\hline Álcali Equivalente / Equivalent Alkali (como $\left.\mathrm{Na}_{2} \mathrm{O}\right)$ & $0.83 \%$ \\
\hline \multicolumn{2}{|l|}{ Componentes Potenciales / Potential Compounds } \\
\hline $\mathrm{C}_{3} \mathrm{~S}$ & $54.0 \%$ \\
\hline $\mathrm{C}_{2} \mathrm{~S}$ & $17.9 \%$ \\
\hline $\mathrm{C}_{3} \mathrm{~A}$ & $10.3 \%$ \\
\hline $\mathrm{C}_{4} \mathrm{AF}$ & $7.9 \%$ \\
\hline \multicolumn{2}{|l|}{ Análisis Físico / Physical Analysis } \\
\hline Finura malla $45 \mathrm{~mm}$ / Fineness $45 \mathrm{~mm}$ Sieve & $87.1 \%$ pasa \\
\hline Finura Blaine / Blaine & $385 \mathrm{~m}^{2} / \mathrm{kg}$ \\
\hline Tiempo de Fraguado - Inicial / Setting Time - Initial & 155 minutes \\
\hline Expansión Autoclave / Autoclave Expansion & $0.01 \%$ \\
\hline Expansión Sulfatos / Sulphate expansion & $0.011 \%$ \\
\hline Resistencia a compresión a 3 días / Compressive strength at 3 days & $26.0 \mathrm{MPa}$ \\
\hline Resistencia a compresión a 7 días / Compressive strength at 7 days & $31.1 \mathrm{MPa}$ \\
\hline Resistencia a compresión a 28 días / Compressive strength at 28 days & $38.4 \mathrm{MPa}$ \\
\hline
\end{tabular}

Tabla 3. Proporciones de mezcla (por $\left.\mathrm{m}^{3}\right)$

Table 3. Mixture proportions (per $\mathrm{m}^{3}$ )

\begin{tabular}{|c|c|c|c|c|c|c|c|c|c|}
\hline $\begin{array}{l}\text { Número de la Mezcla / } \\
\text { Mixture Number }\end{array}$ & $\begin{array}{l}\mathrm{A} / \mathrm{C} \\
W / C\end{array}$ & $\begin{array}{l}\text { Cemento kg / } \\
\text { Cement kg }\end{array}$ & CA kg & FA $\mathrm{kg}$ & $\begin{array}{l}\text { Agua kg / } \\
\text { Water kg }\end{array}$ & AEA ml & HRWR ml & Set Ret ml & $\mathrm{CI} \mathrm{L}$ \\
\hline 1 & 0.3 & 673 & 890 & 470 & 202 & 471 & 1000 & --- & --- \\
\hline 2 & 0.4 & 505 & 1105 & 720 & 133 & 303 & --- & --- & --- \\
\hline 4 & 0.4 & 505 & 890 & 610 & 202 & 253 & 3000 & 631 & $\mathrm{CNI}, 25$ \\
\hline 6 & 0.5 & 404 & 890 & 694 & 202 & 202 & --- & --- & --- \\
\hline 7 & 0.6 & 336 & 750 & 890 & 202 & 100 & --- & --- & --- \\
\hline
\end{tabular}

CA: agregado grueso; FA: agregado fino; AEA: Aditivo incorporador de aire; HRWR: reductor de agua de alto rango; Set Ret: Retardante de fraguado; Cl: Inhibidor de corrosión

CA: Coarse Aggregate; FA: Fine Aggregate; AEA: Air Entrainer Admixture; HRWA: High Range Water Reducer; Set. Ret: Set Retarder; Cl: corrosion inhibitor 


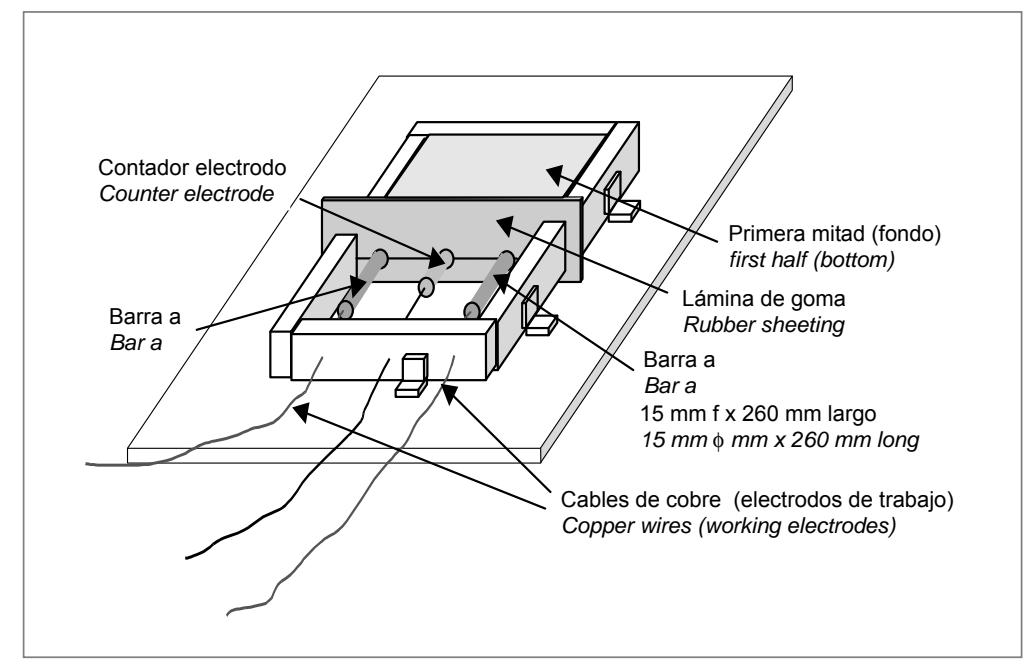

Figura 1. Presentación esquemática de las muestras

Figure 1. Schematic representation of specimens

Las losas de concreto recibieron curado húmedo por 28 días a de $23 \pm 2^{\circ} \mathrm{C}$, con una humedad relativa de no menos de $95 \%$ antes de ser ubicadas en el sitio de exposición.

En la Tabla 4 se muestran los detalles de los inhibidores de corrosión usados en el programa de prueba.
The concrete slabs were moist cured for 28 days at $23 \pm 2{ }^{\circ} \mathrm{C}$ at a relative humidity of not less than 95\% before being placed at the exposure site.

The details on the corrosion inhibitors used in this testing program are given in Table 4.

Tabla 4. Detalles de los inhibidores de corrosión usados en el programa de prueba

Table 4. Details on the corrosion inhibitor used in the testing program

\begin{tabular}{||c|c|}
\hline Tipo de Inhibidor / Type of inhibitor & Ingrediente Activo / Active ingredient \\
\hline CNI - inhibidor anódico de corrosión / \\
CNI - anodic corrosion inhibitor & $30 \%$ Nitrato de Calcio / \\
& $30 \%$ calcium nitrite \\
\hline
\end{tabular}

La mezcla 2 era una mezcla de control y no contenía inhibidor de corrosión. El inhibidor comercial basado en nitrato de calcio $\mathrm{CNI}$ que también se usó en este estudio contiene un mínimo de $30 \%$ de nitrato de calcio. El inhibidor se agregó a la mezcla 4 durante el proceso de mezclado. De acuerdo al fabricante, este inhibidor anódico estabiliza la capa del film de óxido protector en la superficie del acero y cubre los defectos en el film de óxido (W.R Grace 1996). Cuando se agrega al concreto en suficiente cantidad, se debe mantener un sistema activo de control de corrosión dentro de la matriz del concreto. En este estudio se usó $25 \mathrm{~L} / \mathrm{m}^{3}$ de $\mathrm{CNI}$ tal como lo recomienda el fabricante. En síntesis, el agregar inhibidor de corrosion no tuvo un efecto notable en el desempeño del concreto fresco y de su resistencia a compresión (Kondratova et al., 2003 y Montes et al., 2005).
Mixture 2 was a control mixture and did not contain corrosion inhibitor. The commercial anodic calcium nitrite-based corrosion inhibitor (CNI) that was also used in this study contains a minimum $30 \%$ of calcium nitrite. The inhibitor was added to the concrete during the mixing process for concrete mixture 4. According to the manufacturer, this anodic inhibitor stabilizes the protective oxide film layer on the steel surface and covers defects in the protective oxide film (W.R. Grace, 1996). When added to the concrete in sufficient quantity, it should maintain an active corrosion controlling system within the concrete matrix. In this study, $25 \mathrm{~L} / \mathrm{m}^{3}$ of the CNI corrosion inhibitor was used as recommended by the manufacturer. The addition of corrosion inhibitors did not have any noticeable effect on the workability of fresh concrete and on its compressive strength (Kondratova et al. 2003 and Montes et al., 2005). 


\section{Resultados}

El estudio originalmente fue ideado para evaluar el efecto de la relación A/C y el ancho del preagrietamiento en densidad de corriente de corrosión de la muestra. Aún más, se consideró el efecto del preagrietado en el concreto que contenía $25 \mathrm{~L} / \mathrm{m}^{3}$ de CNI. A continuación se presenta un breve resumen de los resultados.

\subsection{Inspección visual}

Los resultados de la inspección para las muestras después de cinco años de exposición al ambiente natural marino se presentan en la Tabla 5. De la información se puede observar que prácticamente todas las muestras mostraron una desgaste extenso, agrietamiento y desconche principalmente causado por la corrosión del acero reforzadote refuerzo. Sin embargo, otros factores externos como el efecto maremoto, o varias tormentas severas ocasionales pueden inducir a un proceso de mayor deterioro. Las losas de menor escala son susceptibles a la penetración rápida de agentes agresivos que los elementos más grandes y de mayor espesor al ser sometidos cualquier ambiente desfavorable. Sin embargo, la información proporcionada es útil y será fundamental para entender la corrosión cuando se complementa con los resultados de la prueba electromagnética.

Después de cuatro años de exposición las muestras con $\mathrm{A} / \mathrm{C}$ entre 0.3 y 0.4 grieta preformada, no presentaron agrietamiento, pero durante el quinto año se produjo un deterioro serio y actualmente muestran un agrietamiento visible. Sin embargo, la extensión del agrietamiento es más bajo que lo observado para las muestras de relación A/C 0.5 y 0.6

Aun no está claro el efecto en corrosión de una grieta pre-formada. Actualmente, todas las muestras con grieta pre-formada muestran agrietamiento adicional debido a la corrosión; sin embargo, la inspección visual después de cuatro anos de exposición reveló señales que grietas entre 0.1 y $0.4 \mathrm{~mm}$ preformadas aparentemente causaron agrietamiento más pronto que en las preagrietadas de 0.2 y $0.3 \mathrm{~mm}$.

Para las muestras de relación A/C 05 y 0.6 el pre-agrietamiento no parece tener ninguna influencia en las grietas causadas por corrosión, y es su baja resistencia a la penetración de agentes agresivos a lo largo de la barra de refuerzo lo cual determina su nivel de deterioro. Esto se confirmó por el extensivo deterioro de la superficie de concreto observada, y del agrietamiento en otros lados que llevó a una eventual desintegración de la muestra.

\section{Results}

The study was originally intended to evaluate the effect of $w / c$ ratio and precrack width on the corrosion current density of specimens. Furthermore, the effect of precracking in concrete containing $25 \mathrm{~L} / \mathrm{m}^{3}$ of $\mathrm{CNI}$ was also considered. A brief summary of results is presented next.

\subsection{Visual examination}

Results of visual inspection for specimens after five years of exposure to the natural marine environment are presented in Table 5. From the data it can be seen that practically all the specimens exhibited extensive rusting, cracking and spalling mostly caused by corrosion of the reinforcing steel. However, other extraneous factors like the tidal effect or occasional severe storms may have induced further deterioration. Furthermore, there is the possibility that the small size of the specimens contributed to the acceleration of the deterioration process. Smallscale slabs are prone to rapid penetration of aggressive agents as opposed to larger and thicker elements subjected to any harsh environment. Nevertheless, the information provided is useful and will be fundamental to the understanding of corrosion when it is complemented with results from electrochemical testing.

After four years of exposure 0.3 and $0.4 \mathrm{w} / \mathrm{c}$ ratio specimens without a preformed crack experienced no cracking, but during the fifth year they underwent serious deterioration and currently they show visible cracking. However, the extent of cracking is lower than that observed for 0.5 and $0.6 \mathrm{w} / \mathrm{c}$ ratio specimens.

The effect of a preformed crack on corrosion is not yet clear. At the present time, all the specimens with a preformed crack show additional cracking due to corrosion; however, visual inspection after four years of exposure revealed signs that 0.1 and $0.4 \mathrm{~mm}$ preformed cracks apparently caused cracking to occur sooner than 0.2 and $0.3 \mathrm{~mm}$ precracks.

For 0.5 and $0.6 \mathrm{w} / \mathrm{c}$ ratio specimens, precracking does not appear to have an influence on cracking caused by corrosion, and it is their low resistance to the penetration of aggressive agents along the rebar which determines their rate of deterioration. This is confirmed by the extensive concrete surface deterioration which was observed, and cracking elsewhere which led to the eventual crumbling of the specimen. 
Tabla 5. Inspección visual de muestras a largo plazo en un ambiente natural marítimo Table 5. Visual inspection of long-term specimens at the natural marine environment

\begin{tabular}{|c|c|c|c|c|c|}
\hline $\begin{array}{c}\text { Espécimen \# / } \\
\text { spec.\# }\end{array}$ & $\begin{array}{l}\mathrm{A} / \mathrm{C} \\
W / C\end{array}$ & $\begin{array}{l}\text { Pre-agrietamiento / } \\
\text { Precrack }\end{array}$ & $\begin{array}{l}\text { Corrosión protección / } \\
\text { corrosion protection }\end{array}$ & 4 años & 5 años \\
\hline 1 & 0.3 & No agrietado /uncracked & nil & - & $\mathrm{a}, \mathrm{cc}$ \\
\hline 2 & 0.3 & 0.1 & nil & $\mathrm{a}, \mathrm{b}, \mathrm{cc}, *$ & $\mathrm{a}, \mathrm{b}, \mathrm{cc}, *$ \\
\hline 3 & 0.3 & 0.2 & nil & $\mathrm{a}, \mathrm{cc}, \mathrm{rt}$ & $a, b, c c, r t$ \\
\hline 6 & 0.4 & No agrietado /uncracked & nil & - & $\mathrm{a}, \mathrm{cc}$ \\
\hline 7 & 0.4 & 0.1 & nil & $a, b, c c, r t$ & $a, b, c c$ \\
\hline 8 & 0.4 & 0.2 & nil & $\mathrm{a}, \mathrm{cc}, \mathrm{rt}$ & $a, b, c c$ \\
\hline 9 & 0.4 & 0.3 & nil & Rt & $\mathrm{a}, \mathrm{b}, \mathrm{cc}$ \\
\hline 13 & 0.5 & 0.2 & nil & $\mathrm{rt}, \mathrm{NI}, *$ & $\mathrm{rt}^{*}$ \\
\hline 14 & 0.5 & 0.3 & nil & $*$ & $\mathrm{rt}^{*}$ \\
\hline 15 & 0.5 & 0.4 & nil & $a, b, c c$ & $\mathrm{a}, \mathrm{b}, \mathrm{cc}$ \\
\hline 16 & 0.6 & No agrietado /uncracked & nil & $a, b$ & NA \\
\hline 17 & 0.6 & 0.1 & nil & $\mathrm{a}, \mathrm{cc}$ & $\mathrm{a}, \mathrm{b}, \mathrm{cc} *$ \\
\hline 18 & 0.6 & 0.2 & nil & Rt & $\mathrm{a}, \mathrm{cc}, \mathrm{rt}$ \\
\hline 19 & 0.6 & 0.3 & nil & $\mathrm{rt}^{*}$ & $\mathrm{a}, \mathrm{b}, \mathrm{cc},{ }^{*}$ \\
\hline 20 & 0.6 & 0.4 & nil & NA & NA \\
\hline
\end{tabular}

La Tabla 5 también indica que las muestras de relación $\mathrm{A} / \mathrm{C} 0.4$ que tuvieron $\mathrm{CNI}$ experimentaron en general menos agrietamiento que aquellas sin inhibidores después de cuatro años de exposición en un ambiente natural. Esto fue más evidente para las muestras sin grietas preformadas, las cuales hasta ahora no muestran señales de agrietamiento. Por otro lado, las muestras pre-agrietadas muestran agrietamiento, el cual a pesar de ser ligeramente menor que en las muestra sin $\mathrm{CNI}$, aun es significativo. De hecho algunas porciones de losa se quebraron produciendo exposición de la barra de acero. Sin embargo, la causa de esos quiebres es incierta y más no se puede extraer conclusiones aun.

\subsection{Prueba electroquímica}

Las condiciones de corrosión de las muestras se monitorearon por un periodo de 5 años usando la técnica LPR y los resultados se resumen en la Figura 2. La información presentada representa el valor promedio $\mathrm{I}_{\text {corr }}$ de dos barras de reforzamiento incrustadas en losas de concreto de pequeña escalas. Los valores que faltan indican ya sea que las muestras fueron ubicadas en el segundo año o la incapacidad para testear debido al daño parcial o total de las muestras causadas por un entorno ambiental severo.
Table 5 also indicates that $0.4 \mathrm{w} / \mathrm{c}$ specimens having CNI experienced in general less cracking than specimens without inhibitors after four years of exposure to the natural environment. This was more evident for the specimens without a preformed crack, which show no signs of cracking so far. On the other hand, precracked specimens show cracking which, even though slightly less than that observed for specimens without $\mathrm{CNI}$, is still significant. In fact, some slab portions broke off exposing the steel bar. Nevertheless, the cause of these breaks is uncertain and further conclusions cannot be drawn.

\subsection{Electrochemical Testing}

The corrosion condition of specimens was monitored for a period of five years using LPR technique and the results are summarized in Figure 2. The data presented represent the $I_{\text {corr }}$ average value of two reinforcing bars embedded in small-scale concrete slabs. Missing values indicate either that specimens were placed on the second year or the inability to perform the testing due to partial or total damage to the specimens caused by the severe environment. 
Figura 2 muestra, primero que $\mathrm{I}_{\text {corr }}$ aumenta con el tiempo. Todas las lecturas se tomaron a mediados del verano cuando hay condiciones apropiadas para el desarrollo de corrosión. La mayoría de las muestras tuvieron un valor $\mathrm{I}_{\text {corr }}$ mayor que $1 \mu \mathrm{A} / \mathrm{Cm}^{2}$ indicando que se está produciendo corrosión activa. Sólo unas muestras no agrietadas en relaciones de A/C 0.3 y 0.4 tuvieron valores $\mathrm{I}_{\text {corr }}$ menores que $1 \mu \mathrm{A} / \mathrm{Cm}^{2}$, denotando que estaba ocurriendo una corrosión de características baja a moderada (Broomfield, 1997).

\section{a) Efecto de la relación}

A/C tuvo una influencia significativa en la densidad de la corrosion. $\mathrm{I}_{\text {corr }}$ fue menor en las relaciones $\mathrm{A} / \mathrm{C}$ inferiores y aumentó para los relaciones $\mathrm{A} / \mathrm{C}$ superiores respectivamente; así la relación $0.3 \mathrm{~A} / \mathrm{C}$ tuvo un mejor desempeño al retrasar o reducir corrosión. Algunas muestras de relación A/C 0.5 y 0.6 fallaron y no fueron posibles pruebas de desempeño posteriores, como se muestra en las Figuras 2c y $2 \mathrm{~d}$.
Figure 2 shows, first of all, that $I_{\text {corr }}$ increases with time. All the readings were taken in the mid-summer when the conditions are appropriate for corrosion to develop. Most of the specimens had an $I_{\text {corr }}$ value higher that $1 \mu \mathrm{A} / \mathrm{cm} 2$ indicating that active corrosion is taking place. Only a few uncracked in 0.3 and $0.4 \mathrm{w} / \mathrm{C}$ ratio specimens had $I_{\text {corr }}$ values less than $1 \mu \mathrm{A} / \mathrm{cm} 2$, denoting that low to moderate corrosion was occurring (Broomfield 1997).

\section{a) Effect of $w / c$ Ratio}

W/c ratio had an unquestionably significant influence on the corrosion current density. $I_{\text {corr }}$ was lower in low $w / c$ ratios and increased for high $w / c$ ratios accordingly; thus, $0.3 \mathrm{w} / \mathrm{c}$ performed the best in delaying or reducing corrosion. Some 0.5 and $0.6 \mathrm{w} / \mathrm{c}$ ratio specimens had failed and further testing was not possible to perform as shown in Figure $2 c$ and $2 d$.
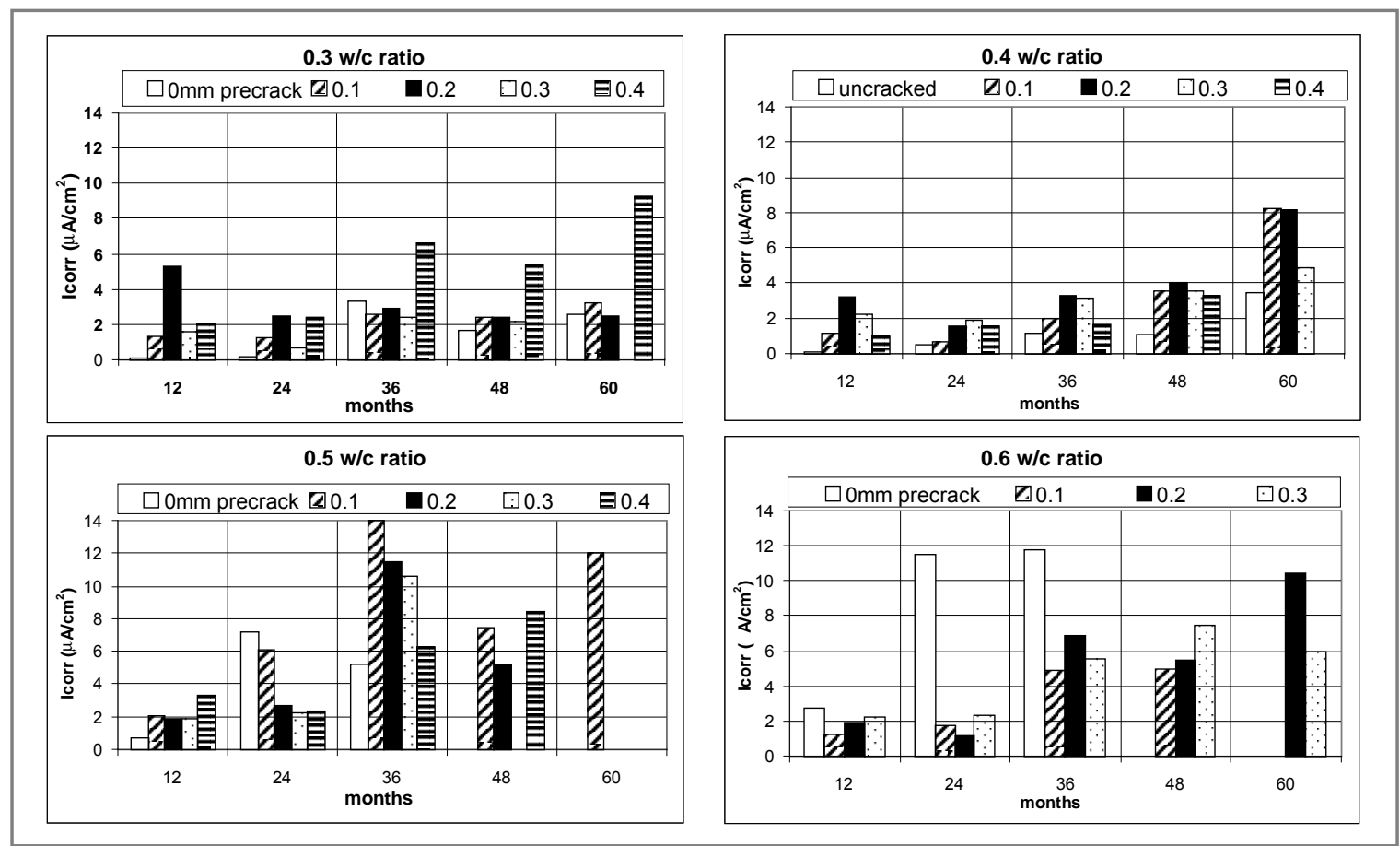

Figura 2. Efecto de la relación $\mathrm{A} / \mathrm{C}$ y tamaño de la grieta en concreto sometida al ambiente natural marino

Figure 2. Effect of $\mathrm{w} / \mathrm{c}$ ratio and crack size in concrete subjected to a natural marine environment

\section{b) Efecto del ancho de pre-agrietamiento}

El pre-agrietado tuvo un efecto marcado en $\mathrm{I}_{\text {corr }}$ para las relaciones $\mathrm{A} / \mathrm{C} 0.3$ y 0.4 , mientras que para los relaciones A/C 0.5 y 0.6 su efecto no es claro. Sin embargo, el ancho del pre-agrietado no parece aumentar el valor $\mathrm{I}_{\text {corr }}$ para la mayoría de los relaciones $\mathrm{A} / \mathrm{C}$.

\section{b) Effect of Precrack Width}

Precracking had a marked effect on Icorr for 0.3 and $0.4 \mathrm{w} / \mathrm{c}$ ratio, whereas for 0.5 and $0.6 \mathrm{w} / \mathrm{c}$ ratio its effect is not clear. However, the width of precracks does not appear to increase the lcorr value for most of the $w / c$ ratios. 
Por ejemplo en la relación A/C 0.3 el valor $\mathrm{I}_{\text {corr }}$ máximo registrado fue de pre-agrietado $0.4 \mathrm{~mm}$ (Figura 2a), y para el relación A/C 0.4 el máximo fue consistente con un pre-agrietado de $0.2 \mathrm{~mm}$ a través de los años (Figura 2b). Para las relaciones A/C 0.5 y 0.6 el efecto del ancho del pre-agrietado es también incierto, principalmente por el bajo número de muestras disponibles para prueba en etapas posteriores.

\section{c) Efecto CNI en relación $\mathrm{A} / \mathrm{C} 0.4$}

Los valores $\mathrm{I}_{\text {corr }}$ para muestras que contienen $25 \mathrm{~L} / \mathrm{m}^{3}$ de $\mathrm{CNI}$ en general son mas bajos que las muestras que no contienen $\mathrm{CNI}$ (comparar Figuras 3 y 4). Sin embargo, esto tiene una alta dosificación de CNI aparentemente no detuvo la corrosión en concreto no agrietado. A pesar que la muestra no está experimentando grietas, su valor $\mathrm{I}_{\text {corr }}$ ha aumentado con el tiempo alcanzando más de $2 \mu \mathrm{A} / \mathrm{Cm}^{2}$. Esto es una indicación que un índice alto de corrosión esta ocurriendo y el agrietado es cosa de tiempo.

\section{d) Comparación del Ancho del Efecto Pre-Agrietado en Concreto que contiene $25 \mathrm{~L} / \mathrm{m}^{3}$ of $\mathrm{CNI}$}

Las lecturas después de uno dos años de exposición sugieren que hay un efecto aparente de ancho de pre-agrietado que aumenta las lecturas $I_{\text {corr }}$. Sin embargo, mayores pruebas indican que el máximo de actividad de corrosión no se relaciona con un pre-agrietado más ancho (Figura 4). Resultados similares se obtienen para muestras hechas con A/C 0.4 sin inhibidor, y esto fue descubierto desde el comienzo del la prueba (Figura 3)
For example, in $0.3 \mathrm{w} / \mathrm{c}$ ratio the maximum $I_{\text {corr }}$ value registered was for $0.4 \mathrm{~mm}$ precrack (Figure 2a), and for $0.4 \mathrm{w} / \mathrm{c}$ ratio the maximum was consistently $0.2 \mathrm{~mm}$ precrack over the years (Figure 2b). For 0.5 and $0.6 \mathrm{w} / \mathrm{c}$ ratios the effect of precrack width is also unclear, mainly because of the low number of specimens available for testing at later ages.

\section{c) Effect of CNI in $0.4 \mathrm{w} / \mathrm{c}$ Ratio}

The $I_{\text {corr }}$ values for specimens containing 25 $\mathrm{L} / \mathrm{m}^{3}$ of $\mathrm{CN}$ I are in general lower than for specimens containing no CNI (compare Figures 3 and 4). However, this high dosage of $\mathrm{CNI}$ apparently did not stop corrosion even in uncracked concrete. In spite of the specimen is not experiencing cracking, its Icorr value has been increasing over time reaching more than $2 \mu \mathrm{A} / \mathrm{cm}^{2}$. This is an indication that a high corrosion rate is occuring and the occurence of cracking is only a matter of time.

\section{d) Comparison of the Effect of Precrack Width in Concrete Containing $25 \mathrm{~L} / \mathrm{m}^{3}$ of $\mathrm{CNI}$}

Readings after one and two years of exposure suggest that there is an apparent effect of precrack width increasing the $I_{\text {corr }}$ readings. However, further testing indicates that the maximum corrosion activity is not related to the wider precrack (Figure 4). Similar results were obtained for specimens made of $0.4 \mathrm{w} / \mathrm{c}$ ratio with no inhibitor and this was noted since the beginning of the test (Figure 3).

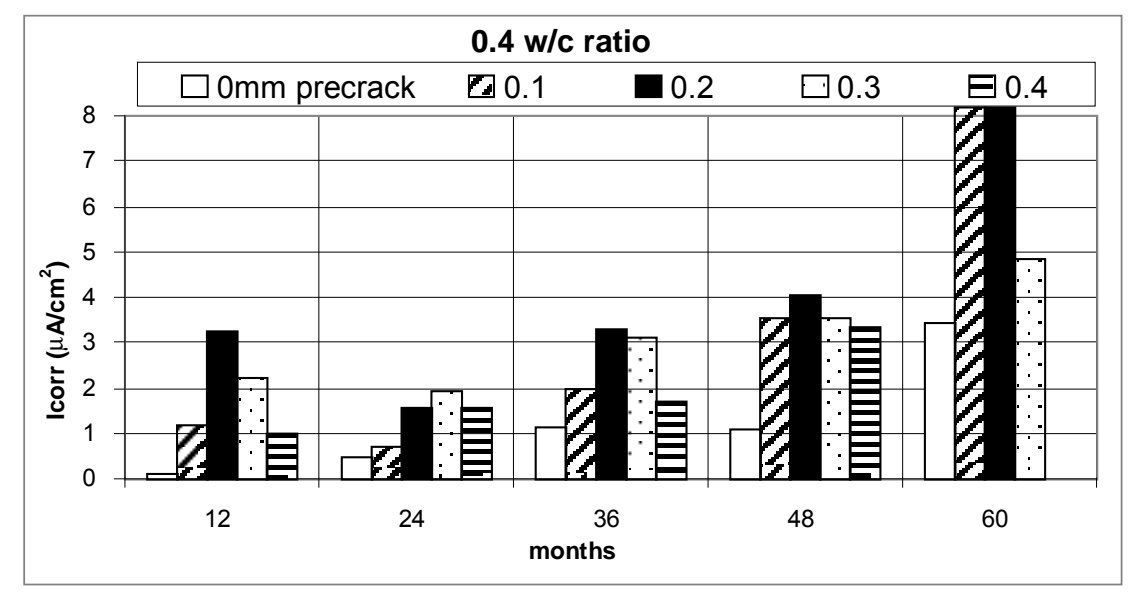

Figura 3. Efecto del pre-agrietado en relación $0.4 \mathrm{w} / \mathrm{c}$

Figure 3. Effect of precracking in $0.4 \mathrm{w} / \mathrm{c}$ ratio 


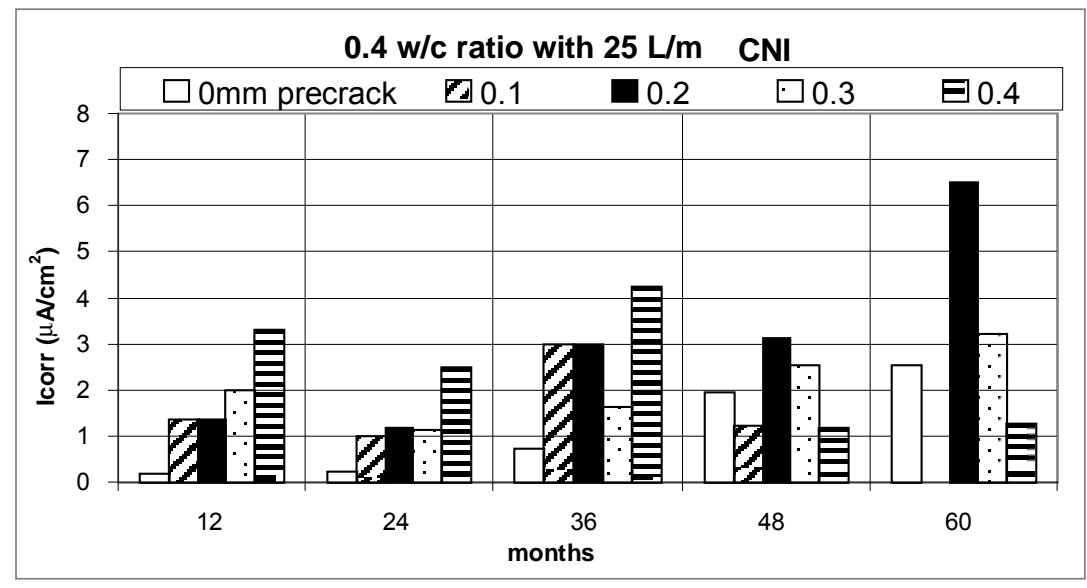

Figura 4. Efecto del pre-agrietado en relación $0.4 \mathrm{w} / \mathrm{c}$ que contiene $25 \mathrm{~L} / \mathrm{m}^{3}$ de CNI

Figure 4. Effect of precracking in $0.4 \mathrm{w} / \mathrm{C}$ ratio containing $25 \mathrm{~L} / \mathrm{m}^{3}$ of $\mathrm{CNI}$

\section{Conclusiones y recomendaciones}

En base a los hallazgos derivados del programa experimental, se pueden hacer las siguientes recomendaciones y conclusiones en relación a la efectividad del inhibidor de corrosión de nitrato de calcio:

\subsection{Conclusiones}

El CNI no fue efectivo para disminuir la corrosión en losas de concreto en A/C 0.4 con recubrimiento de $20 \mathrm{~mm}$ para cada concreto ya sea para condiciones de concreto pre-agrietado o no pre-agrietado hasta 36 meses de exposición. Sin embargo, a los 60 meses no se puede notar un efecto positivo de $\mathrm{CNI}$.

EI CNI retrasa la corrosión en concreto no agrietado; sin embargo, en los resultados del concreto agrietado se revela que el CNI proviene sólo de un efecto de beneficio marginal.

La baja relación $\mathrm{A} / \mathrm{C}$ tiene un efecto positivo al disminuir el agrietamiento debido a su fuerza de tensión mejorada. Sin embargo, el agrietamiento es casi inevitable, cuando hay una alta cantidad de cemento presente en el concreto, causado por reacciones naturales.

El efecto del agrietado para concreto de cemento portland común, en rangos de relación $\mathrm{A} / \mathrm{C}$ entre 0.5 y 0.6 es prácticamente insignificante en corrosión, sin embargo, para relaciones $\mathrm{A} / \mathrm{C}$ de 0.3 y 0.4 la existencia de agrietamientos es importante.

\section{Conclusions and recommendations}

Based on the findings derived from the experimental program, the following conclusions and recommendations can be made regarding the effectiveness of calcium nitrite corrosion inhibitor:

\subsection{Conclusions}

$\mathrm{CNI}$ was not effective in decreasing corrosion in $0.4 \mathrm{w} / \mathrm{c}$ concrete slabs with $20 \mathrm{~mm}$ cover for either precracked or not precracked concrete conditions up to 36 months of exposure. However, at 60 months a positive effect of $\mathrm{CNI}$ can be noted.

$\mathrm{CN}$ I delays corrosion in uncracked concrete; however, in cracked concrete results reveal that CNI provides only a marginal beneficial effect.

Low $w / c$ ratio has a positive effect in decreasing cracking due to its improved tensile strength. However, when a high amount of cement in present in the concrete the appearance of cracking caused by naturally occurring reactions is almost inevitable.

The effect of cracking for ordinary portland cement concrete, in $w / c$ ratios ranging between 0.5 and 0.6 is practically insignificant on corrosion; however, for 0.3 and $0.4 \mathrm{w} / \mathrm{c}$ ratios the existence of cracking is important. 


\subsection{Recomendaciones para futuras investigaciones}

Se requiere mayor investigación en inhibidores de corrosión y agrietamiento para condiciones de exposición a largo plazo y debería involucrar miembros estructurales escala 1:1 bajo carga, para producir agrietamiento por flexión bajo exposición marina. Los resultados obtenidos de esta investigación se deberían usar para planear experimentos a largo plazo.

\section{Reconocimientos}

El apoyo del Consejo Nacional de Ciencia y Tecnología de Mexico (CONACYT), Institutop Politécnico Nacional de Mexico (IPN) y se reconoce gratamente el apoyo del Natural Science and Engineering Research Council de Canada (NSERC).

\subsection{Recommendations for Future Research}

More research is needed on corrosion inhibitors and cracking for long-term exposure conditions and it should involve full scale structural members loaded back to back to produce flexural cracking and subjected to marine exposure. The results obtained from this research should be used in planning these long-term experiments.

\section{Acknowledgements}

The support of National Council of Science and Technology of Mexico (CONACYT), National Polytechnic Institute of Mexico (IPN) and Natural Science and Engineering Research Council of Canada (NSERC) is gratefully acknowledged.

\section{Referencias / References}

Broomfield J. P. (1997), Corrosion of Steel in Concrete, Understanding, Investigation and Repair, E \& FN SPON, U. K. Berke N., Pfeifer D.W., Weil T.G. (1988), Protection against chloride induced corrosion, Concrete International, 10 (12) 45-55. Erdogdu S. (1992), Determination of the State of Corrosion of Epoxy-Coated Rebar in Concrete, Ph. D. Dissertation, Faculty of Civil Engineering, University of New Brunswick, September.

Erdogdu S., Bremner T. W. y Kondratova I. L. (2001), Accelerated Testing of Plain and Epoxy-coated reinforcement in Simulated Seawater and Chloride Solutions, Cement and Concrete Research, 31, 861-867

Francois R., Arliguie G. (1998), Influence of service cracking on reinforcement steel corrosion, Journal of Materials for Civil Engineering, 14-20. Francois R, Arliguie G. (1999), Reinforced concrete: correlation between cracking and corrosion, In: Malhotra VM, editor, Second CANMET/ACI International Conference on Durability of Concrete, vol. II, 1221-38, Montreal, Canada.

Gerhardus H. Koch, Michael P. H. Brongers, Neil G. Thompson, Y. Paul Virmani, Joe H. Payer, Corrosion Cost and Preventive Strategies in the United States, Report FHWA-RD-01-166, Office of Infrastructure Research and Development, Federal Highway Administrelacionn, 6300 Georgetown Pike, McLean VA 22101-2296.

Jacobsen S., Marchand J., Gerard B. (1998), Concrete cracks I: durability and self healing-a review, In: Gjorv OE, Sakai K, Banthia N., Proceedings of the Second International Conference on Concrete Under Severe Conditions, Environment and Loading, vol. 1, 217-31, Tromso, Norway.

Kondratova I. (1999), Epoxy Coating and Other Protective Measures for Reinforcing Steel Embedded in Concrete Subjected to a Chloride Laden Environment. Ph. D. Dissertation., Faculty of Civil Engineering, University of New Brunswick, September.

Kondratova I., Montes P. y Bremner T. (2003), Natural marine exposure results for reinforced concrete slabs with corrosion inhibitors, Cement and Concrete Composites 25, 483-490.

Kosmatka S., Kerkhoff B., Panarese C. (2002), Design and Control of Concrete Mixtures, 14a Edition, Portland Cement Association. Montes P., Bremner T. y Mrawira F. (2005), Effects of CNI and fly ash on the compressive strength of high performance concrete, $\mathrm{ACl}$ Materials Journal, 102 (1), 3-8.

Neville A.M. (1999), How useful is the water-cement relacion, Concrete International 21, 69-70.

Nmai CK, McDonald D. (1999), Long-term effectiveness of corrosion inhibiting admixtures and implications on the design of durable reinforced concrete structures: a laboratory investigation, International Symposium on The Role of Admixtures in High Performance Concrete, 21-26, Monterrey, Mexico.

Schießel P, Dauberschmidt C. Evaluation of calcium nitrite as a corrosion inhibitor (2000) Sixth CANMET/ACI International Conference on Superplasticizers and Other Chemical Admixtures in Concrete, Supplementary Papers, 105-119, Nice, France.

Schießel P, Raupach M. (1997), Laboratory studies and calculations on the influence of crack width on chloride-induced corrosion of steel in concrete, ACI Materials Journal 19 (1), 56-62.

W. R. Grace (1996), How DCI Works, W.R. Grace, MA, USA, 1996. 